\title{
Phytohormone pathways as targets of pathogens to facilitate infection
}

\author{
Ka-Wai Ma ${ }^{1,2} \cdot$ Wenbo Ma ${ }^{1,2}$
}

Received: 2 September 2015/Accepted: 7 February 2016/Published online: 15 February 2016

(c) The Author(s) 2016. This article is published with open access at Springerlink.com

\begin{abstract}
Plants are constantly threatened by potential pathogens. In order to optimize the output of defense against pathogens with distinct lifestyles, plants depend on hormonal networks to fine-tune specific responses and regulate growth-defense tradeoffs. To counteract, pathogens have evolved various strategies to disturb hormonal homeostasis and facilitate infection. Many pathogens synthesize plant hormones; more importantly, toxins and effectors are produced to manipulate hormonal crosstalk. Accumulating evidence has shown that pathogens exert extensive effects on plant hormone pathways not only to defeat immunity, but also modify habitat structure, optimize nutrient acquisition, and facilitate pathogen dissemination. In this review, we summarize mechanisms by which a wide array of pathogens gain benefits from manipulating plant hormone pathways.
\end{abstract}

Keywords Plant immunity - Pathogen effectors · Phytohormones $\cdot$ Pathogenicity $\cdot$ Virulence $\cdot$ Bacterial toxins

K.-W. Ma and W. Ma have contributed equally to this manuscript.

Ka-Wai Ma

kma007@ucr.edu

$\triangle$ Wenbo Ma

wenbo.ma@ucr.edu

1 Department of Plant Pathology and Microbiology, University of California, Riverside, CA 92521, USA

2 Center for Plant Cell Biology, University of California, Riverside, CA 92521, USA

\section{Introduction}

In order to complete an infection cycle, phytopathogens need to enter plant tissues through physical barriers, overcome defense responses mounted by the plant immune system, obtain nutrients for proliferation, and eventually be disseminated to a new host. During the co-evolutionary arms race with plants, successful pathogens evolved virulence factors such as toxins and secreted proteins (aka effectors) to modulate plant physiology (Bender et al. 1999; TortoAlalibo et al. 2009; Dou and Zhou 2012; Dangl et al. 2013). A prominent and extensively studied example is the type III secreted effectors, which are injected by Gram negative bacterial pathogens directly into plant cells (Deslandes and Rivas 2012; Feng and Zhou 2012). Eukaryotic filamentous pathogens including fungi and oomycetes also produce a large number of effectors that can function inside host cells (Torto-Alalibo et al. 2009; Wawra et al. 2012; Giraldo and Valent 2013). Over the past decade, substantial efforts have been invested to understand how effectors facilitate pathogen colonization and disease development. Through these studies, phytohormone pathways have emerged as important virulence targets.

Plant hormones are small molecules that affect a broad range of processes during growth and stress responses (Depuydt and Hardtke 2011; Pieterse et al. 2012; Vanstraelen and Benkova 2012). By manipulating plant hormonal pathways, pathogens can further benefit through two mechanisms: one, they can suppress defense responses regulated by the "stress" hormones in order to accomplish colonization in plant tissues; two, they can hijack plant development and nutrient allocation processes regulated by the "growth" hormones to facilitate sustained colonization and dissemination.

In this review, we classify major plant hormones into "stress" and "growth" hormones and discuss the mechanisms 
by which microbial pathogens interfere with their accumulation and/or signaling. Due to space constrains, we will focus on pathogen effectors and toxins that have been demonstrated to directly manipulate hormonal networks in plants as virulence strategies to increase pathogen fitness. Examples from a wide variety of pathogens (viruses, bacteria, fungi, oomycetes and herbivores) using different infection strategies will be discussed.

\section{Plant hormones as key regulators of immunity}

Unlike animals that can move and adapt to survive suboptimal conditions, plants are sessile; therefore, the ability to defeat pathogen infection is critical to survival. Threatened by a large variety of pests and pathogens, plants have evolved a sophisticated innate immune system (Spoel and Dong 2012). A basal tier of plant immunity is activated by conserved molecular signatures called pathogen/microbeassociated molecular patterns (PAMPs/MAMPs), which can be recognized by receptor-like kinases known as pattern recognition receptors (PRRs) (Zipfel 2014). Pattern-triggered immunity (PTI) is associated with a series of physiological responses that confer effective, broad-spectrum defense against the majority of potential pathogens (Bigeard et al. 2015). Shortly after pathogen perception, extensive transcription reprogramming of genes involved in hormonal signaling occurs (De Vos et al. 2005), suggesting a key regulatory role of hormones in mounting defense responses.

Major plant hormones that regulate defense responses include salicylic acid (SA), jasmonic acid (JA) and ethylene (ET). Generally speaking, SA plays a key role in defense against pathogens feeding on live tissues, i.e. with a biotrophic lifestyle; and JA/ET is critical to defense against pathogens feeding on dead tissues, i.e. with a necrotrophic lifestyle (Glazebrook 2005). In addition, JA alone is prominent in defense against herbivores (Fig. 1). An important concept that has been established over the years is the antagonism between SA and JA/ET pathways in response to pathogens with a specific lifestyle (Spoel and Dong 2008; Van der Does et al. 2013). However, analysis using a mutant that is defective in SA, JA and ET pathways supported a more synergistic view in that all three hormones contribute positively to defense against various pathogens with one hormone sector makes larger contributions than others in response to a specific infection style (Tsuda et al. 2009).

\section{Toxins and effectors targeting salicylic acid accumulation}

SA is the first plant hormone with a demonstrated role in defense (White 1979) and has since been studied extensively. Provided the importance of SA in plant defense, many pathogens have evolved strategies to target the SA pathway, either at the level of biosynthesis/accumulation or downstream signaling (Fig. 1).

A main virulence strategy is to suppress SA accumulation through the activity of secreted enzymes that metabolize SA precursors. For example, the biotrophic fungal pathogen Ustilago maydis, which causes maize smut, produces a chorismate mutase (Cmu1) during infection.
Fig. 1 A diagram showing the crosstalk among SA, JA and ET signaling pathways and their roles in defense against pathogens/herbivores using distinctive infection strategies. Effectors and toxins target SA, JA and ET signaling to suppress plant defense are presented. Virulence factors produced by biotrophs/hemibiotrophs are highlighted in blue, and those produced by necrotrophs are highlighted in red. Chorismate mutase and isochromatases are produced by both biotrophs and necrotrophs and are highlighted in green. Broken lines indicate indirect manipulation processes or unknown mechanisms

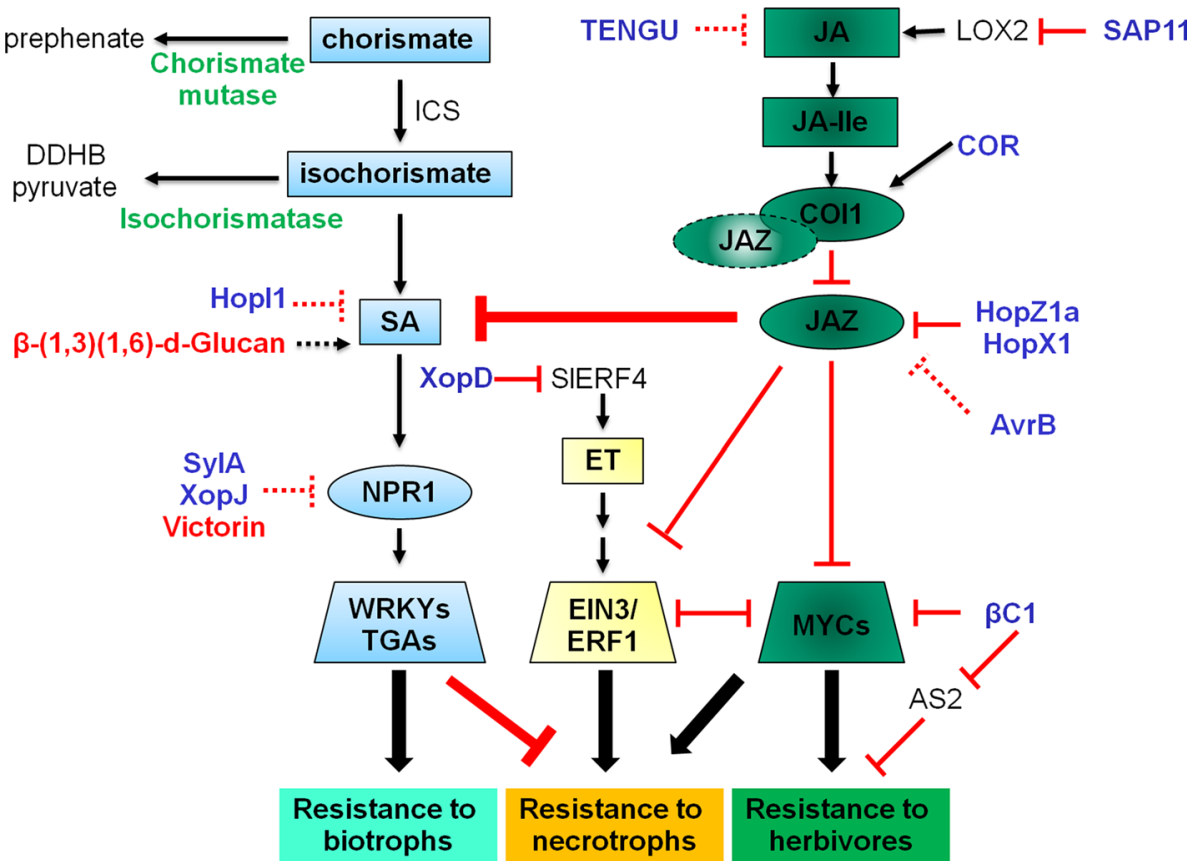


Following pathogen perception, SA is produced from chorismate via the intermediate isochorismate through the activity of the isochorismate synthase (ICS) (Wildermuth et al. 2001). Cmul converts chorismate to prephenate, potentially lowering the availability of plastid chorismate for SA synthesis (Djamei et al. 2011). Indeed, maize infected with a Cmul mutant of $U$. maydis accumulated more SA and exhibited attenuated disease symptoms compared with plants infected with wild-type strain (Djamei et al. 2011). Many biotrophic and hemibiotrophic pathogens produce chorismate mutases that can potentially benefit infection (Djamei et al. 2011). Interestingly, the necrotrophic fungal pathogen Sclerotinia sclerotiorum also produces a putative chorismate mutase. Pretreatment of the SA analog benzothiadiazole (BTH) on rapeseed plants resulted in an approximately $40 \%$ reduction on lesion sizes caused by $S$. sclerotiorum, suggesting a positive role of SA in defense against $S$. sclerotiorum (Novakova et al. 2014). This observation indicates that the putative chorismate mutase produced by $S$. sclerotiorum may promote infection by reducing SA accumulation.

Another secreted enzyme with the ability to suppress SA accumulation is isochorismatase, which is produced by the hemibiotrophic oomycete pathogen Phytophthora sojae and the necrotrophic fungal pathogen Verticillium dahlia. Isochorismatase hydrolyzes isochorismate to 2,3-dihydro2,3-dihydroxybenzoate (DDHB) and pyruvate. As such, $P$. sojae and $V$. dahlia reduce the SA levels in their specific hosts to facilitate infection (Liu et al. 2014). These studies demonstrate the suppression of SA accumulation as a common virulence strategy employed by both biotrophic and necrotrophic pathogens.

Enhanced SA accumulation may benefit pathogens using a distinctive infection strategy and in specific hostpathogen interactions. For instance, the broad host-range, necrotrophic, fungal pathogen Botrytis cinerea produces exopolysaccharide $\beta$-(1,3)(1,6)-D-glucan, which acts as an essential virulence factor by inducing SA accumulation, and hence suppressing JA signaling, in tomato (El Oirdi et al. 2011). Other interesting observations are that the mucus secreted by molluscan slugs and snails, and the honeydew deposited by whitefly could induce the expression of the SA marker gene PRI (Meldau et al. 2014; VanDoorn et al. 2015). Intriguingly, SA was found in the mucus of the slug Deroceras reticulatum (Kastner et al. 2014) and honeydew of the sweetpotato whitefly Bemisia tabaci (VanDoorn et al. 2015). Since the activation of SA signaling may suppress JA-mediated defense against herbivores, it would be interesting to investigate whether these herbivores-produced SA actually play a role in promoting infestation.

In addition to the above virulence factors with relatively clear SA manipulation mechanisms, other effectors have also been suggested to affect SA accumulation. For example, HopI1 produced by the hemibiotrophic bacterial pathogen Pseudomonas syringae suppresses SA accumulation in chloroplasts. HopI1 directly interacts with the heat shock protein Hsp70 and alters chloroplast thylakoid structure (Jelenska et al. 2007, 2010). However, how HopI1 interferes with SA production remains elusive.

\section{Toxins and effectors targeting salicylic acid signaling}

NPR1 (NONEXPRESSOR OF PR GENES 1) is an essential component in SA-dependent defense. Upon pathogen perception, SA potentiates the reduction of the oligomeric form of NPR1 in cytoplasm to a monomeric form through redox changes (Mou et al. 2003). Monomeric NPR1 is then relocated to the nucleus and activates the expression of SA-responsive genes. NPR1-regulated SA signaling is tightly regulated through post-translational modifications and proteasomal degradation. In particular, proper turnover of NPR 1 is required for the perpetuation of SA response (Tada et al. 2008; Spoel et al. 2009). Therefore, it is not surprised that NPR1 turnover is manipulated by various pathogens for the benefit of disease development.

The bacterial pathogen $P$. syringae produces a peptide toxin, syringolin A (SylA), which acts as a potent inhibitor of proteasomes (Groll et al. 2008; Schellenberg et al. 2010). SylA can diffuse through plant vasculature, generating a gradient of SA-insensitive cells and suppressing SA-mediated defense both at the initial infection site and in surrounding tissues (Misas-Villamil et al. 2013). It is postulated that SylA blocks the proteasomal degradation of NPR1 to interfere with SA signaling. The type III-secreted effector XopJ from the bacterial pathogen Xanthomonas campestris acts as a protease and degrades the 19S proteasome regulatory subunit REGULATORY PARTICLE AAA-ATPASE6 (RPT6). As such, XopJ inhibits NPR1 degradation and compromises anti-bacterial immunity in pepper (Üstün et al. 2013; Ustun and Bornke 2015).

The toxin victorin produced by the necrotrophic fungal pathogen Cochliobolus victoriae can suppress the activity of TRX-h5, a thioredoxin that regulates the redox status in plants (Sweat and Wolpert 2007). By inhibiting the redox reduction of NPR1, victorin may suppress SA-mediated defense via interfering with NPR1 relocation from cytosol to the nucleus. However, $C$. victoriae does not seem to take advantage of NPR1 manipulation by victorin as a virulence strategy. Rather, as a necrotrophic pathogen, C. victoriae uses victorin to induce plant cell death by hijacking the hypersensitive response triggered by LOV1, a resistance (R) protein that is activated when TRX-h5 is disturbed (Sweat and Wolpert 2007; Lorang et al. 2012). Indeed, $C$. 
victoriae only causes disease on Arabidopsis ecotypes that carry LOV1 (Lorang et al. 2004). Nonetheless, victorin represents a novel strategy of pathogen manipulation of NPR1.

\section{Toxins and effectors targeting jasmonate signaling}

JA is the major defense hormone against necrotrophs and herbivores. Although the ability to suppress JA signaling has been implicated in some herbivores (Zarate et al. 2007; Bruessow et al. 2010; Glas et al. 2014), the responsible molecules or underlying mechanisms are unknown. On the contrary, many virulence factors produced by biotrophic or hemibitrophic pathogens take advantage of the antagonism between JA and SA pathways and activate JA signaling to promote infection (Fig. 1).

Jasmonic acid signaling is repressed by a group of proteins collectively known as the JASMONATE ZIMDOMAIN proteins (JAZs) (Staswick 2008). Inside the nucleus, JAZs directly associates with the JA-responsive transcription factors and repress their functions (Pauwels et al. 2010; Shyu et al. 2012). Upon activation by pathogen perception or tissue damage, JA is synthesized from linolenic acid via 12-oxo-phytodienoic acid (OPDA) as the intermediate in plastids and conjugated with isoleucine to generate the bioactive form JA-Ile (Staswick and Tiryaki 2004; Fonseca et al. 2009). High levels of JA-Ile promote the formation of a receptor complex consisting of JAZs, the F-box protein COI1, and inositol pentakisphosphate. Association with COI1 leads to proteasomal degradation of JAZs, thereby de-repressing JA signaling (Thines et al. 2007; Melotto et al. 2008; Sheard et al. 2010).

The toxin coronatine (COR) produced by the bacterial pathogen $P$. syringae pv. tomato strain DC3000 (PtoDC3000) is by far the best studied example of virulence factors that can manipulate the JA pathway. Structurally mimicking JA-Ile, COR is $\sim 1000$ fold more effective in inducing the degradation of JAZs and acts as a robust inducer of JA signaling (Katsir et al. 2008). Plants respond to bacterial invasion by closing stomata in order to inhibit pathogen entry into the apoplastic space. Activation of JA signaling by COR promotes the entry of PtoDC3000 into leaf tissues by re-opening the closed stomata (Melotto et al. 2006). In addition, COR inhibits SA accumulation in plant cells, likely also through its activation of JA signaling (Zheng et al. 2012).

A COR-like compound, coronafacic acid (CFA)-L-Ile, is produced by various pathogenic Streptomyces species that cause potato scab disease (Bignell et al. 2010). CFA-LIle is required for the full virulence of Streptomyces; furthermore, application of CFA-L-Ile can induce hypertrophic outgrowths on potato, suggesting that this toxin may contribute to disease symptom development (Fyans et al. 2015). Although COR can also induce a similar phenotype on potato, whether the virulence function of CFA-L-Ile during Streptomyces infection is achieved through JA mimicking is unknown.

Acting as effective virulence factors, COR-like toxins are only produced by a small number of bacterial pathogens (for example, most $P$. syringae isolates do not produce COR) (Volksch and Weingart 1998; Hwang et al. 2005); therefore, it is not surprising to find additional pathogen strategies for JA manipulation. In particular, several type III effectors from $P$. syringae have recently been shown to directly or indirectly promote JAZ degradation. HopZ1a possesses an acetyltransferase activity and directly interacts with multiple JAZs in Arabidopsis and soybean. Acetylation of JAZs by HopZ1a promotes their degradation in a COI1-dependent manner and activates JA signaling (Jiang et al. 2013). Another P. syringae effector that activates JA signaling is HopX1, which acts as a cysteine protease and directly hydrolyzes JAZs in Arabidopsis (Gimenez-Ibanez et al. 2014). Recently, a third type III effector AvrB was shown to induce JAZs degradation, but through an indirect mechanism (Zhou et al. 2015). Similar to COR, HopZ1a and AvrB are also able to inhibit stomatal defense and promote bacterial entry to apoplastic space (Ma et al. 2015; Zhou et al. 2015). The findings that multiple virulence factors, including both toxins and effectors, manipulate the same host targets highlight the importance of JA pathway as a virulence target.

\section{Manipulation of jasmonate signaling to promote pathogen dissemination}

Many bacterial and viral pathogens depend on insect vectors for transmission. Since JA is a major defense hormone against insects, these pathogens have evolved strategies to suppress JA accumulation and/or signaling in order to promote their dissemination.

Phytoplasmas are bacterial pathogens that depend on phloem-feeding leafhoppers for transmission. The Aster Yellows phytoplasma strain Witches' Broom (AY-WB) produces a Sec-secreted effector called SAP11, which destabilizes the TEOSINTE BRANCHED1, CYCLOIDEA, PROLIFERATING CELL FACTORS (TCP) class of transcription factors in Arabidopsis (Ikeda and OhmeTakagi 2014). Among them, TCP4 activates the expression of JA biosynthetic gene LIPOXYGENASE 2 (LOX2) (Schommer et al. 2008). AY-WB infection or SAP11 expression in Arabidopsis led to reduced $L O X 2$ expression and JA levels; as a result, the fecundity of leafhoppers was increased and the transmission of AY-WB was enhanced (Sugio et al. 2011). TENGU is another phytoplasma Secsecreted effector that has been shown to suppress JA 
accumulation. TENGU represses the expression of two auxin-response factors ARF6 and ARF8 (Hoshi et al. 2009), which positively regulate JA biosynthesis (Reeves et al. 2012). It has been postulated that, similar to SAP11, TENGU may also facilitate leafhopper feeding, and hence phytoplasma transmission, by manipulating the JA pathway (Minato et al. 2014).

A similar scenario exists in the interaction between tomato yellow leaf curl China virus (TYLCCNV) and its whitefly vector. TYLCCNV produces $\beta C 1$ as a virulence factor to suppress anti-herbivore volatile emission and promote whitefly survival (Jiu et al. 2007; Zhang et al. 2012). $\beta C 1$ acts as a mimic of the plant regulator ASYMMETRIC LEAVES 2 (AS2) (Yang et al. 2008), which inhibits JA signaling (Nurmberg et al. 2007). In addition, $\beta C 1$ also inhibits the dimerization of MYC2, a JA-responsive transcription factor required for the activation of the terpene synthetic gene TERPENE SYNTHASE 10 (TPS10) (Li et al. 2014). Interestingly, AS2 and MYC2 seem to regulate distinct subsets of JA-responsive genes (Li et al. 2014). As such, $\beta \mathrm{C} 1$ suppresses JA signaling to favor viral transmission by simultaneously manipulating two targets that regulate the JA response (Jiu et al. 2007; Zhang et al. 2012).

\section{Manipulation of ethylene levels by pathogens to promote infection}

Together with JA, ethylene (ET) has been shown to regulate defense against necrotrophs (Thomma et al. 1999). As a gaseous hormone, ET is widely produced by many microorganisms including plant pathogens. For example, the bacterial pathogen $P$. syringae and Ralstonia solanacearum, as well as the fungal pathogen $B$. cinerea, can all produce ET (Weingart and Volksch 1997; Cristescu et al. 2002; Valls et al. 2006). Furthermore, the ability to produce ET is correlated with the full virulence of $P$. syringae strains on soybean and common bean (Weingart et al. 2001), indicating a potential virulence function of ET production in these pathogens.

An effector that can manipulate the ET pathway has been identified from the bacterial pathogen Xanthomonas euvesicatoria. XopD targets the tomato transcription factor SIERF4, which is involved in ET synthesis. Acting as a SUMO protease, XopD desumoylates SIERF4, promoting its degradation through the 26S proteasome. Consistently, silencing of SIERF4 led to reduced ET accumulation and enhanced susceptibility of tomato to X. euvesicatoria (Kim et al. 2013). In addition, XopD delays chlorosis development on tomato leaves infected with $X$. euvesicatoria, which is likely due to its inhibitory effect on ET production (Kim et al. 2008, 2013). It is postulated that the modulation of ET-regulated senescence benefits bacterial proliferation by extending the infection period.

\section{Manipulation of the abscisic acid pathway by pathogens}

More recently, abscisic acid (ABA), which has been extensively studied in plant response to abiotic stresses, is also implicated in defense responses. ABA acts as a negative regulator of defense against biotrophs (Cao et al. 2011), possibly due to its antagonistic effect on SA signaling (Audenaert et al. 2002; Xu et al. 2013). For example, exogenous application of $\mathrm{ABA}$ in rice significantly reduced the expression of two key regulators of SA-dependent defense signaling, WRKY45 and OSNPRI, leading to hypersusceptibility to fungal infection (Jiang et al. 2010).

A couple of type III effectors produced by the bacterial pathogen $P$. syringae have been suggested to activate the ABA pathway during infection. AvrPtoB induces the expression of the ABA biosynthetic gene 9-CIS-EPOXYCAROTENOID DIOXYGENASE 3 (NCED3) and enhances ABA accumulation in Arabidopsis (de Torres-Zabala et al. 2007). Since AvrPtoB has been extensively characterized as a kinase inhibitor and directly targets receptor kinases (Shan et al. 2008; Cheng et al. 2011), its effect on ABA synthesis is likely indirect. Another type III effector HopAM1 also affects ABA signaling. Arabidopsis expressing HopAM1 exhibits increased sensitivity to ABA and enhanced susceptibility to bacterial infection (Goel et al. 2008). Although the correlation between these two observed phenotypes remains unclear, it is noteworthy that the hypersensitive response is associated with inhibited vascular water movement into the infection site. A drop in water potential presumably deprives the water supply that is required for bacteria to proliferate (Wright and Beattie 2004; Freeman and Beattie 2009). Interestingly, the virulence effect of HopAM1 was more prominent when the host plants were under water stress (Goel et al. 2008). It is intriguing to postulate that HopAM1 may create a microenvironment with higher water availability through its manipulation of $\mathrm{ABA}$ signaling in order to promote bacterial infection. Since the direct plant target(s) of HopAM1 is unknown, the potential mechanism by which HopAM1 modulates ABA signaling to benefit infection remains unclear.

Although clear evidence demonstrating pathogen factors directly targeting the ABA pathway for virulence is lacking, various pathogenic fungi produce ABA themselves (Dorffling et al. 1984; Jiang et al. 2010). For example, ABA was found in the hyphae of the rice blast pathogen Magnaporthe grisea (Jiang et al. 2010) and several other fungal pathogens including $B$. cinerea, Fusarium oxysporum and Rhizoctonia solani (Dorffling et al. 1984). Further studies are needed to address the role of the fungi-originated $\mathrm{ABA}$ in potential suppression of SA-dependent defense during infection. 


\section{Effectors targeting the growth hormones to indirectly regulate defense}

In addition to the "stress" hormone (SA, JA and ET), another group of hormones, including auxin, cytokinin (CK), gibberellin (GA) and brassinosteroid (BR), have been traditionally known as "growth" hormones based on their prominent regulatory role in plant growth and development. Due to extensive crosstalk among hormonal pathways, virulence factors can indirectly suppress plant defense by manipulating the growth hormones. In parallel, pathogens can directly benefit from the modulation of growth hormonal pathways, independent of defense suppression. For example, specific pathogens, such as the gall-forming bacteria, hijack hormonal regulation of plant growth to induce tumorigenesis and acquire shelter and nutrients. Morphological changes due to disturbed homeostasis of growth hormones could also facilitate pathogen dissemination.

\section{Toxins and effectors suppress plant defense by modulating the auxin pathway}

Auxin is the first and most-studied plant hormone that affects almost all aspects of growth and development (Chandler and Werr 2015; Salehin et al. 2015; Schaller et al. 2015). In general, auxin affects plant immunity by acting as a negative regulator (Ludwig-Muller 2015; Naseem et al. 2015). Such an effect is likely achieved through antagonism of auxin signaling on the SA pathway. For example, overexpression of an auxin receptor AUXIN SIGNALING F- BOX PROTEINS 1 (AFB1) led to reduced SA accumulation and enhanced susceptibility during PtoDC3000 infection (Robert-Seilaniantz et al. 2011). Furthermore, overexpression of the auxin biosynthetic gene YUCCAl (YUCl) in SA-deficient plants can further promote infection, suggesting that auxin also impacts defense output in a SA-independent manner (Mutka et al. 2013).

As a negative regulator of defense response, auxin signaling is repressed during infection. For example, perception of bacterial and oomycete PAMPs induces the accumulation of microRNA393 (miR393) in Arabidopsis and soybean, respectively (Navarro et al. 2006; Wong et al. 2014). miR393 contributes to PTI by repressing auxin signaling through its inhibitory effect on the expression of auxin receptors (Navarro et al. 2006). Furthermore, several effectors, such as the bacterial type III effector HopT1-1 produced by $P$. syringae (Navarro et al. 2008) and the oomycete effector PSR1 produced by $P$. sojae, have been shown to suppress the miRNA pathway (Qiao et al. 2013, 2015). These effectors may promote infection by activating auxin signaling and suppressing PTI.

An important strategy to perturb auxin homeostasis is to produce auxin-like molecules, which is quite common in plant pathogens and non-pathogenic microorganisms associating with plants (Manulis et al. 1994; Glickmann et al. 1998; Robert-Seilaniantz et al. 2007). Certain $P$. syringae isolates encode the IAA-conjugation enzyme IAA-LYSINE SYNTHASE (IAAL), which is under the control of a pathogenicity-associated sigma factor. Importantly, deletion of iaaL led to reduced virulence, supporting a role of IAA synthesis during $P$. syringae infection (Castillo-Lizardo et al. 2015).

Auxin accumulation and transport can be manipulated via the virulence activities of effectors. The $P$. syringae type III effector AvrRpt2 promotes auxin biosynthesis (Chen et al. 2007) and induces auxin-responsive gene expression by enhancing the proteasomal degradation of AUXIN/INDOLE ACETIC ACID (AUX/IAA) proteins, the key negative regulators of auxin signaling (Cui et al. 2013). Another P. syringae type III effector HopM1 associates with ADP ribosylation factor (ARF) guanine nucleotide exchange factor 5 in Arabidopsis (aka AtMIN7) and promotes its degradation. As AtMIN7 is involved in recycling the auxin-efflux carrier PINFORMED (PIN1) (Tanaka et al. 2013), HopM1 may disrupt polar auxin transport and increase plant susceptibility (Nomura et al. 2006). Auxin transport can also be disrupted by the hemibiotrophic oomycete pathogen Phytophthora parasitica through the function of PSE1, which affects the expression of the auxin efflux carriers PIN4 and PIN7 (Evangelisti et al. 2013). In this way, PSE1 may facilitate Phytophthora infection by disrupting auxin physiology.

Auxin signaling can also be manipulated by viruses. The replicase protein of tobacco mosaic virus (TMV) interacts with the AUX/IAA protein PHYTOCHROME-ASSOCIATED PROTEIN 1 (PAP1) and induces its accumulation in the cytoplasm; consequently, the expression of auxin-responsive genes is repressed due to decreased levels of nuclear-localized PAP1. Importantly, a TMV replicase mutant strain with diminished interaction with PAP1 exhibited reduced viral titer in plants, suggesting that the inhibition of auxin signaling is an important virulence mechanism of TMV (Padmanabhan et al. 2005, 2006, 2008).

\section{Modulation of the cytokinin pathway to suppress plant defense}

Cytokinin regulates defense response in a dosage-dependent manner. Strong activation of CK signaling leads to increased SA levels and confers resistance to biotrophs; on the contrary, subtle or weak activation of $\mathrm{CK}$ signaling suppresses PTI, likely in an SA-independent manner (Hann et al. 2014). CK accumulation can be modulated by the type III effector HopQ1, which belongs to a conserved effector family that is produced by a variety of bacterial 
pathogens including Pseudomonas spp., Xanthomonas spp. and Ralstonia spp. (Hann et al. 2014). HopQ1 possesses a hydrolase activity that can catalyze the conversion of $\mathrm{CK}$ precursors to active forms. As a result, HopQ1 expression in Arabidopsis led to elevated accumulation of $\mathrm{CK}$ and hypersusceptibility to bacterial infection. Interestingly, exogenous applications of low doses of CK repressed the transcription of the PAMP-receptor gene FLAGELLIN SENSING 2 (FLS2), indicating that HopQ1 dampens PTI by suppressing PRR expression (Hann et al. 2014).

\section{Effectors that potentially manipulate the brassinosteroid pathway}

As a relatively young hormone, brassinosteroid (BR) has been shown to regulate a wide array of developmental processes and stress responses (Kong et al. 2012; Zhu et al. 2013; De Bruyne et al. 2014). Indeed, BR signaling has been reported to regulate plant defense both positively (Chinchilla et al. 2007; Heese et al. 2007) and negatively (De Vleesschauwer et al. 2012; Nahar et al. 2013). Current studies of BR-mediated regulation in defense are centered on the BRI1 ASSOCIATED RECEPTOR KINASE 1 (BAK1/SERK3). Originally identified as a co-receptor of the BR receptor BRASSINOSTEROID INSENSITIVE 1 (BRI1) (Li et al. 2002; Nam and Li 2002), BAK1 was later discovered to associate with multiple PRRs and play an essential role in ligand binding and PTI signaling (Chinchilla et al. 2007; Heese et al. 2007; Sun et al. 2013). Remarkably, several bacteria effectors directly target BAK1 and suppress PTI. The first examples of BAK1manipulating type III effectors are AvrPto and AvrPtoB of $P$. syringae (Shan et al. 2008; Cheng et al. 2011). By suppressing the kinase activity of BAK1 and PRRs (Shan et al. 2008; Xiang et al. 2008; Cheng et al. 2011), AvrPto and AvrPtoB play an essential role in bacterial infection, primarily by disrupting PTI signaling. Two additional type III effectors, HopF2 produced by $P$. syringae and Xoo2875 produced by the rice pathogen Xanthomonas oryzae pv. oryzae (Xoo), can also associate with BAK1 in Arabidopsis and rice respectively (Yamaguchi et al. 2013; Zhou et al. 2014); however, how HopF2 and Xoo2875 may manipulate BAK1 function remains to be elucidated.

A challenge to dissect the contribution of BR to defense response is the dual roles of BAK1 in both PTI and BR signaling (Albrecht et al. 2012; Belkhadir et al. 2012). In addition, BAK1 has also been shown to act as a co-receptor for PEP RECEPTOR1 (PEPR1), which is involved in the perception of damage-associated molecular patterns (DAMPs) (Schulze et al. 2010). Provided the diverse roles of BAK1 in distinctive signaling pathways, whether these BAK1-targeting effectors benefit infection through a potential disruption of BR signaling, as well as other pathways such as the DAMP signaling, requires careful investigation. Furthermore, BR signaling has been proposed to negatively regulate immunity through a role in regulating growth/defense tradeoff (Lozano-Duran and Zipfel 2015). Therefore, it is possible that pathogens may benefit from manipulating BR signaling through targeting components not directly involved in PTI.

\section{Pathogen hijacking growth hormone homeostasis to enhance nutrient acquisition}

In addition to defense suppression, pathogens gain additional benefits from disturbing growth hormone homeostasis (Fig. 2). One of the benefits is nutrient allocation into infected tissues for sustained pathogen proliferation. Many pathogens produce cytokinins (CKs) to facilitate translocation of nutrients into infected sites. These areas are known as "green islands" because they exhibit delayed senescence and support continuous growth of the pathogen population (Walters and McRoberts 2006; Walters et al. 2008).

Gall-forming bacteria are well-known for their ability to produce CK. For example, the bacterial pathogen Rhodococcus fascians produces a mixture of six different $\mathrm{CK}$ mimics. Genes involved in $\mathrm{CK}$ biosynthesis and metabolism are encoded on a large linear plasmid pFiD188, and the loss of pFiD188 rendered the bacterium unable to cause disease (Crespi et al. 1992; Radhika et al. 2015). However, introduction of one CK biosynthesis gene cluster into this avirulent mutant failed to complement the

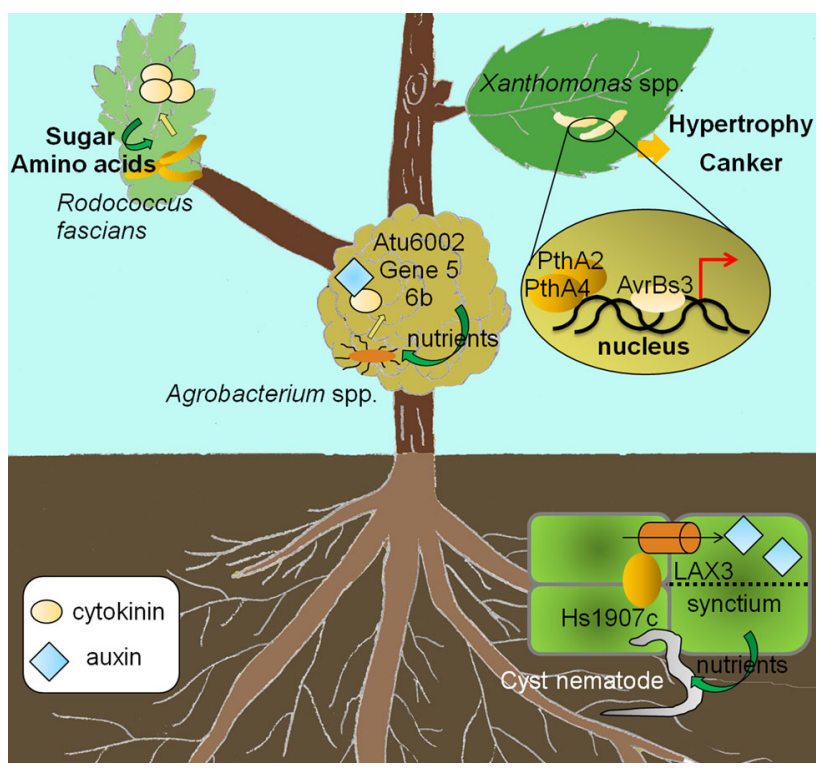

Fig. 2 Effectors interfering with growth hormones cytokinin and auxin to acquire shelter and nutrients, as well as to facilitate pathogen dissemination 
phenotype (Crespi et al. 1992). Therefore, it is likely that various forms of $\mathrm{CKs}$ produced by $R$. fascians work together to facilitate infection (Depuydt et al. 2009a; Pertry et al. 2009, 2010). Interestingly, high levels of sugar and amino acids are accumulated in $R$. fascians-induced galls; these nutrients are presumably resulted from the production of CKs by $R$. fascians to support bacterial proliferation (Depuydt et al. 2009b).

The crown gall disease pathogens Agrobacterium spp. carry auxin and CK biosynthetic genes within the T-DNA region, which are incorporated into the genome of susceptible plants to induce tumorigenesis (Schroder et al. 1984; Thomashow et al. 1986). Moreover, additional Agrobacteria proteins contribute to gall formation by fine-tuning hormonal flux and the ratio between auxin and CK. For examples, gene 5 acts as an auxin antagonist and regulates auxin responsiveness through an autoregulatory loop (Korber et al. 1991); Atu6002 interferes with the perception of auxin in tumor-forming cells (Lacroix et al. 2014); and 6b affects the localization of auxin, and possibly CK, in tumor cells (Takahashi et al. 2013). It is proposed that these proteins function together to promote shoot formation on galls, which extends the lifespan of infected hosts and safeguards a stable food source for the bacterium.

Plant pathogenic nematodes are also known to produce effectors, which can promote infection through the manipulation of the hormonal pathways (Mitchum et al. 2013). Cyst nematodes induce the formation of specialized feeding structures known as syncytia in plant roots. Syncytia are formed by fusions of neighboring root cells and serve as nutrient sinks for the nematodes. Beet cyst nematode produces an effector Hs1907C, which interacts with the AUXIN INFLUX CARRIER (LAX3) and potentially directs the influx of auxin into root cells (Lee et al. 2011). Auxin can then induce lateral root formation and the production of cell wall-modifying enzymes (Swarup et al. 2008), which facilitate syncytia development. Interestingly, transgenic plants expressing $\mathrm{Hs} 1907 \mathrm{C}$ are more resistant to cyst nematodes. A possible explanation is that the overall disturbance of auxin flux in roots may reduce the amount of auxin available for the nematode-feeding sites (Swarup et al. 2008; Lee et al. 2011). If this is true, spatial expression of effector disrupting hormonal homeostasis would be pivotal in determining the outcome of infection.

\section{Effectors manipulate growth hormones to promote dissemination}

The last step to complete an infection cycle is the dissemination of pathogens to new hosts. Several type III effectors known as TRANSCRIPTION ACTIVATORLIKE effectors (TALEs) are produced by Xanthomonas spp. to promote bacterial dissemination by directly activating growth hormone-responsive genes in plant hosts. AvrBs3 from $X$. campestris activates the expression of the transcription factor Upa20 in pepper that regulates auxinresponsive genes. Among them, an expansin-like gene induces hypertrophy of mesophyll cells, which may enhance bacterial release from lesions (Marois et al. 2002; Kay et al. 2007). Similarly, two TALEs, PthA2 and PthA4, produced by the citrus canker pathogen $X$. citri were shown to induce genes involved in ET, GA and auxin signaling pathways. Even though the biological significance of the elevated expression of these genes requires further investigation, gene ontology enrichment analysis suggested that these genes may be associated with cell wall modifications (Pereira et al. 2014), which promote the development of canker pustules (Cernadas and Benedetti 2009). Therefore, PthA2 and PthA4 may contribute to canker formation and facilitate bacterial dissemination to infect new hosts.

\section{Conclusions and future perspectives}

Constantly challenged by potential pathogens in the environment, failure to mount an effective defense response is fatal to plants. Plant hormones have profound impact on immunity, not only through the canonical "defense" hormones, but also through the "growth" hormones, which exhibit bifurcated functions in modulating defense as well as regulating resource allocation (Huot et al. 2014). During the co-evolutionary arms race with their hosts, pathogens have evolved sophisticated strategies to maximize fitness in plants. Therefore, it is not surprising that the plant hormone network has been repeatedly identified as targets of a broad range of pathogens. Although most studies have focused on defense suppression, hijacking the nutrient allocation system and disturbing growth-defense tradeoff is of critical importance to pathogenesis. Therefore, pathogen manipulation of growth hormonal signaling for benefits independent of suppressing immunity cannot be overlooked.

Even though the distinctive roles of SA and JA in regulating defense to biotrophs and necrotrophs have generally been accepted, contradictory findings were also reported. Such discrepancies may be attributed to the use of transgenic plants or hormone analogs in simplified laboratory studies. It is likely that endogenous hormone levels during natural infections hardly fluctuate to a level resulted from experimental manipulations. Since hormonal regulation is a dynamic process with intricate crosstalk, cautions need to be taken when interpreting data from experiments involving extensive perturbation of the network. Changes in nutrient requirement and virulence strategies at different infection stages should also be considered as determining factors to understand specific manipulation of hormonal pathways by a particular pathogen. 
Finally, many plant-associating microorganisms including pathogens and symbionts are shown to directly produce plant hormones. Currently, it is not well understood how these additional hormonal signals generated from the phytobiome may impact plant physiology and pathogen infection. Furthermore, symbiotic organisms can also produce effectors to modulate plant hormonal network and foster colonization (Plett et al. 2014). Studies of effectors from symbiotic microbes and the roles of microbe-originated hormones will provide new insight into our understanding of plant-microbe interactions.

Acknowledgments We thank members in the Ma laboratory, especially Kelley Clark for critical reading of the manuscript. Research in the authors' laboratory is supported by funds from the University of California-Riverside, Citrus Research Board, Citrus Research and Development Foundation, NSF, USDA-AES-RSAP, and USDA-NIFA to W.M. We apologize to colleagues whose work we were unable to cite due to space limitations.

Open Access This article is distributed under the terms of the Creative Commons Attribution 4.0 International License (http://crea tivecommons.org/licenses/by/4.0/), which permits unrestricted use, distribution, and reproduction in any medium, provided you give appropriate credit to the original author(s) and the source, provide a link to the Creative Commons license, and indicate if changes were made.

\section{References}

Albrecht C, Boutrot F, Segonzac C, Schwessinger B, Gimenez-Ibanez S, Chinchilla D, Rathjen JP, de Vries SC, Zipfel C (2012) Brassinosteroids inhibit pathogen-associated molecular patterntriggered immune signaling independent of the receptor kinase BAK1. Proc Natl Acad Sci USA 109:303-308

Audenaert K, De Meyer GB, Hofte MM (2002) Abscisic acid determines basal susceptibility of tomato to Botrytis cinerea and suppresses salicylic acid-dependent signaling mechanisms. Plant Physiol 128:491-501

Belkhadir Y, Jaillais Y, Epple P, Balsemao-Pires E, Dangl JL, Chory J (2012) Brassinosteroids modulate the efficiency of plant immune responses to microbe-associated molecular patterns. Proc Natl Acad Sci USA 109:297-302

Bender CL, Alarcon-Chaidez F, Gross DC (1999) Pseudomonas syringae phytotoxins: mode of action, regulation, and biosynthesis by peptide and polyketide synthetases. Microbiol Mol Biol Rev 63:266

Bigeard J, Colcombet J, Hirt H (2015) Signaling mechanisms in pattern-triggered immunity (PTI). Mol Plant 8:521-539

Bignell DR, Seipke RF, Huguet-Tapia JC, Chambers AH, Parry RJ, Loria R (2010) Streptomyces scabies 87-22 contains a coronafacic acid-like biosynthetic cluster that contributes to plantmicrobe interactions. MPMI 23:161-175

Bruessow F, Gouhier-Darimont C, Buchala A, Metraux JP, Reymond $P$ (2010) Insect eggs suppress plant defence against chewing herbivores. Plant J 62:876-885

Cao FY, Yoshioka K, Desveaux D (2011) The roles of ABA in plantpathogen interactions. J Plant Res 124:489-499

Castillo-Lizardo MG, Aragon IM, Carvajal V, Matas IM, PerezBueno ML, Gallegos MT, Baron M, Ramos C (2015) Contribution of the non-effector members of the HrpL regulon, iaaL and matE, to the virulence of Pseudomonas syringae pv. tomato DC3000 in tomato plants. BMC Microbiol 15:165

Cernadas RA, Benedetti CE (2009) Role of auxin and gibberellin in citrus canker development and in the transcriptional control of cell-wall remodeling genes modulated by Xanthomonas axonopodis pv. citri. Plant Sci 177:190-195

Chandler JW, Werr W (2015) Cytokinin-auxin crosstalk in cell type specification. Trends Plant Sci 20:291-300

Chen Z, Agnew JL, Cohen JD, He P, Shan L, Sheen J, Kunkel BN (2007) Pseudomonas syringae type III effector AvrRpt2 alters Arabidopsis thaliana auxin physiology. Proc Natl Acad Sci USA 104:20131-20136

Cheng W, Munkvold KR, Gao H, Mathieu J, Schwizer S, Wang S, Yan YB, Wang J, Martin GB, Chai J (2011) Structural analysis of Pseudomonas syringae AvrPtoB bound to host BAK1 reveals two similar kinase-interacting domains in a type III Effector. Cell Host Microbe 10:616-626

Chinchilla D, Zipfel C, Robatzek S, Kemmerling B, Nurnberger T, Jones JDG, Felix G, Boller T (2007) A flagellin-induced complex of the receptor FLS2 and BAK1 initiates plant defence. Nature 448:497-500

Crespi M, Messens E, Caplan AB, van Montagu M, Desomer J (1992) Fasciation induction by the phytopathogen Rhodococcus fascians depends upon a linear plasmid encoding a cytokinin synthase gene. EMBO J 11:795-804

Cristescu SM, De Martinis D, Te Lintel Hekkert S, Parker DH, Harren FJ (2002) Ethylene production by Botrytis cinerea in vitro and in tomatoes. Appl Environ Microbiol 68:5342-5350

Cui F, Wu S, Sun W, Coaker G, Kunkel B, He P, Shan L (2013) The Pseudomonas syringae type III effector AvrRpt2 promotes pathogen virulence via stimulating Arabidopsis auxin/indole acetic acid protein turnover. Plant Physiol 162:1018-1029

Dangl JL, Horvath DM, Staskawicz BJ (2013) Pivoting the plant immune system from dissection to deployment. Science 341:746-751

De Bruyne L, Hofte M, De Vleesschauwer D (2014) Connecting growth and defense: the emerging roles of brassinosteroids and gibberellins in plant innate immunity. Mol Plant 7:943-959

de Torres-Zabala M, Truman W, Bennett MH, Lafforgue G, Mansfield JW, Rodriguez Egea P, Bogre L, Grant M (2007) Pseudomonas syringae pv. tomato hijacks the Arabidopsis abscisic acid signalling pathway to cause disease. EMBO J 26:1434-1443

De Vleesschauwer D, Van Buyten E, Satoh K, Balidion J, Mauleon R, Choi IR, Vera-Cruz C, Kikuchi S, Hofte M (2012) Brassinosteroids antagonize gibberellin- and salicylate-mediated root immunity in rice. Plant Physiol 158:1833-1846

De Vos M, Van Oosten VR, Van Poecke RM, Van Pelt JA, Pozo MJ, Mueller MJ, Buchala AJ, Metraux JP, Van Loon LC, Dicke M, Pieterse CM (2005) Signal signature and transcriptome changes of Arabidopsis during pathogen and insect attack. MPMI 18:923-937

Depuydt S, Hardtke CS (2011) Hormone signalling crosstalk in plant growth regulation. Curr Biol 21:R365-R373

Depuydt S, De Veylder L, Holsters M, Vereecke D (2009a) Eternal youth, the fate of developing Arabidopsis Leaves upon Rhodococcus fascians infection. Plant Physiol 149:1387-1398

Depuydt S, Trenkamp S, Fernie AR, Elftieh S, Renou JP, Vuylsteke M, Holsters M, Vereecke D (2009b) An integrated genomics approach to define niche establishment by Rhodococcus fascians. Plant Physiol 149:1366-1386

Deslandes L, Rivas S (2012) Catch me if you can: bacterial effectors and plant targets. Trends Plant Sci 17:644-655

Djamei A, Schipper K, Rabe F, Ghosh A, Vincon V, Kahnt J, Osorio S, Tohge T, Fernie AR, Feussner I, Feussner K, Meinicke P, Stierhof YD, Schwarz H, Macek B, Mann M, Kahmann R (2011) Metabolic priming by a secreted fungal effector. Nature 478:395-398 
Dorffling K, Petersen W, Sprecher E, Urbasch I, Hanssen HP (1984) Abscisic-acid in phytopathogenic fungi of the genera botrytis, ceratocystis, fusarium, and rhizoctonia. $\mathrm{Z}$ Naturforsch $\mathrm{C}$ 39:683-684

Dou D, Zhou JM (2012) Phytopathogen effectors subverting host immunity: different foes, similar battleground. Cell Host Microbe 12:484-495

El Oirdi M, El Rahman TA, Rigano L, El Hadrami A, Rodriguez MC, Daayf F, Vojnov A, Bouarab K (2011) Botrytis cinerea manipulates the antagonistic effects between immune pathways to promote disease development in tomato. Plant Cell 23:2405-2421

Evangelisti E, Govetto B, Minet-Kebdani N, Kuhn ML, Attard A, Ponchet M, Panabieres F, Gourgues M (2013) The Phytophthora parasitica RXLR effector penetration-specific effector 1 favours Arabidopsis thaliana infection by interfering with auxin physiology. New Phytol 199:476-489

Feng F, Zhou JM (2012) Plant-bacterial pathogen interactions mediated by type III effectors. Curr Opin Plant Biol 15:469-476

Fonseca S, Chini A, Hamberg M, Adie B, Porzel A, Kramell R, Miersch O, Wasternack C, Solano R (2009) (+)-7-iso-Jasmonoyl-L-isoleucine is the endogenous bioactive jasmonate. Nat Chem Biol 5:344-350

Freeman BC, Beattie GA (2009) Bacterial growth restriction during host resistance to Pseudomonas syringae is associated with leaf water loss and localized cessation of vascular activity in Arabidopsis thaliana. MPMI 22:857-867

Fyans JK, Altowairish MS, Li Y, Bignell DR (2015) Characterization of the coronatine-like phytotoxins produced by the common scab pathogen Streptomyces scabies. MPMI 28:443-454

Gimenez-Ibanez S, Boter M, Fernández-Barbero G, Chini A, Rathjen JP, Solano R (2014) The bacterial effector HopX1 targets JAZ transcriptional repressors to activate jasmonate signaling and promote infection in Arabidopsis. PLoS Biol 12:e1001792

Giraldo MC, Valent B (2013) Filamentous plant pathogen effectors in action. Nat Rev Microbiol 11:800-814

Glas JJ, Alba JM, Simoni S, Villarroel CA, Stoops M, Schimmel BC, Schuurink RC, Sabelis MW, Kant MR (2014) Defense suppression benefits herbivores that have a monopoly on their feeding site but can backfire within natural communities. BMC Biol 12:98

Glazebrook J (2005) Contrasting mechanisms of defense against biotrophic and necrotrophic pathogens. Annu Rev Phytopathol 43:205-227

Glickmann E, Gardan L, Jacquet S, Hussain S, Elasri M, Petit A, Dessaux Y (1998) Auxin production is a common feature of most pathovars of Pseudomonas syringae. MPMI 11:156-162

Goel AK, Lundberg D, Torres MA, Matthews R, Akimoto-Tomiyama C, Farmer L, Dangl JL, Grant SR (2008) The Pseudomonas syringae type III effector HopAM1 enhances virulence on waterstressed plants. MPMI 21:361-370

Groll M, Schellenberg B, Bachmann AS, Archer CR, Huber R, Powell TK, Lindow S, Kaiser M, Dudler R (2008) A plant pathogen virulence factor inhibits the eukaryotic proteasome by a novel mechanism. Nature 452:755-758

Hann DR, Dominguez-Ferreras A, Motyka V, Dobrev PI, Schornack S, Jehle A, Felix G, Chinchilla D, Rathjen JP, Boller T (2014) The Pseudomonas type III effector HopQ1 activates cytokinin signaling and interferes with plant innate immunity. New Phytol 201:585-598

Heese A, Hann DR, Gimenez-Ibanez S, Jones AME, He K, Li J, Schroeder JI, Peck SC, Rathjen JP (2007) The receptor-like kinase SERK3/BAK1 is a central regulator of innate immunity in plants. Proc Natl Acad Sci USA 104:12217-12222

Hoshi A, Oshima K, Kakizawa S, Ishii Y, Ozeki J, Hashimoto M, Komatsu K, Kagiwada S, Yamaji Y, Namba S (2009) A unique virulence factor for proliferation and dwarfism in plants identified from a phytopathogenic bacterium. Proc Natl Acad Sci USA 106:6416-6421

Huot B, Yao J, Montgomery BL, He SY (2014) Growth-defense tradeoffs in plants: a balancing act to optimize fitness. Mol Plant 7:1267-1287

Hwang MS, Morgan RL, Sarkar SF, Wang PW, Guttman DS (2005) Phylogenetic characterization of virulence and resistance phenotypes of Pseudomonas syringae. Appl Environ Microbiol 71:5182-5191

Ikeda M, Ohme-Takagi M (2014) TCPs, WUSs, and WINDs: families of transcription factors that regulate shoot meristem formation, stem cell maintenance, and somatic cell differentiation. Front Plant Sci 5:427

Jelenska J, Yao N, Vinatzer BA, Wright CM, Brodsky JL, Greenberg JT (2007) AJ domain virulence effector of Pseudomonas syringae remodels host chloroplasts and suppresses defenses. Curr Biol 17:499-508

Jelenska J, van Hal JA, Greenberg JT (2010) Pseudomonas syringae hijacks plant stress chaperone machinery for virulence. Proc Natl Acad Sci USA 107:13177-13182

Jiang CJ, Shimono M, Sugano S, Kojima M, Yazawa K, Yoshida R, Inoue H, Hayashi N, Sakakibara H, Takatsuji H (2010) Abscisic acid interacts antagonistically with salicylic acid signaling pathway in rice-magnaporthe grisea interaction. MPMI 23:791-798

Jiang S, Yao J, Ma K-W, Zhou H, Song J, He SY, Ma W (2013) Bacterial effector activates jasmonate signaling by directly targeting JAZ transcriptional repressors. PLoS Pathog 9:e1003715

Jiu M, Zhou XP, Tong L, Xu J, Yang X, Wan FH, Liu SS (2007) Vector-virus mutualism accelerates population increase of an invasive whitefly. PLoS One 2:e182

Kastner J, von Knorre D, Himanshu H, Erb M, Baldwin IT, Meldau S (2014) Salicylic acid, a plant defense hormone, is specifically secreted by a molluscan herbivore. PLoS One 9:e86500

Katsir L, Schilmiller AL, Staswick PE, He SY, Howe GA (2008) $\mathrm{COI} 1$ is a critical component of a receptor for jasmonate and the bacterial virulence factor coronatine. Proc Natl Acad Sci USA 105:7100-7105

Kay S, Hahn S, Marois E, Hause G, Bonas U (2007) A bacterial effector acts as a plant transcription factor and induces a cell size regulator. Science 318:648-651

Kim JG, Taylor KW, Hotson A, Keegan M, Schmelz EA, Mudgett MB (2008) XopD SUMO protease affects host transcription, promotes pathogen growth, and delays symptom development in Xanthomonas-infected tomato leaves. Plant Cell 20:1915-1929

Kim JG, Stork W, Mudgett MB (2013) Xanthomonas type III effector XopD desumoylates tomato transcription factor SIERF4 to suppress ethylene responses and promote pathogen growth. Cell Host Microbe 13:143-154

Kong XP, Pan JW, Cai GH, Li DQ (2012) Recent Insights into brassinosteroid signaling in plants: its dual control of plant immunity and stomatal development. Mol Plant 5:1179-1181

Korber H, Strizhov N, Staiger D, Feldwisch J, Olsson O, Sandberg G, Palme K, Schell J, Koncz C (1991) T-DNA gene 5 of Agrobacterium modulates auxin response by autoregulated synthesis of a growth hormone antagonist in plants. EMBO J 10:3983-3991

Lacroix B, Gizatullina DI, Babst BA, Gifford AN, Citovsky V (2014) Agrobacterium T-DNA-encoded protein Atu6002 interferes with the host auxin response. Mol Plant Pathol 15:275-283

Lee C, Chronis D, Kenning C, Peret B, Hewezi T, Davis EL, Baum TJ, Hussey R, Bennett M, Mitchum MG (2011) The novel cyst nematode effector protein 19C07 interacts with the Arabidopsis auxin influx transporter LAX3 to control feeding site development. Plant Physiol 155:866-880 
Li J, Wen JQ, Lease KA, Doke JT, Tax FE, Walker JC (2002) BAK1, an Arabidopsis LRR receptor-like protein kinase, interacts with BRI1 and modulates brassinosteroid signaling. Cell 110:213-222

Li R, Weldegergis BT, Li J, Jung C, Qu J, Sun Y, Qian H, Tee C, van Loon JJ, Dicke M, Chua NH, Liu SS, Ye J (2014) Virulence factors of geminivirus interact with MYC2 to subvert plant resistance and promote vector performance. Plant Cell 26: 4991-5008

Liu T, Song T, Zhang X, Yuan H, Su L, Li W, Xu J, Liu S, Chen L, Chen T, Zhang M, Gu L, Zhang B, Dou D (2014) Unconventionally secreted effectors of two filamentous pathogens target plant salicylate biosynthesis. Nat Commun 5:4686

Lorang JM, Carkaci-Salli N, Wolpert TJ (2004) Identification and characterization of victorin sensitivity in Arabidopsis thaliana. MPMI 17:577-582

Lorang J, Kidarsa T, Bradford CS, Gilbert B, Curtis M, Tzeng SC, Maier CS, Wolpert TJ (2012) Tricking the guard: exploiting plant defense for disease susceptibility. Science 338:659-662

Lozano-Duran R, Zipfel C (2015) Trade-off between growth and immunity: role of brassinosteroids. Trends Plant Sci 20:12-19

Ludwig-Muller J (2015) Bacteria and fungi controlling plant growth by manipulating auxin: balance between development and defense. J Plant Physiol 172:4-12

Ma KW, Jiang S, Hawara E, Lee D, Pan S, Coaker G, Song J, Ma W (2015) Two serine residues in Pseudomonas syringae effector HopZ1a are required for acetyltransferase activity and association with the host co-factor. New Phytol 208:1157-1168

Manulis S, Shafrir H, Epstein E, Lichter A, Barash I (1994) Biosynthesis of indole-3-acetic acid via the indole-3-acetamide pathway in Streptomyces spp. Microbiology 140(Pt 5):1045-1050

Marois E, Van den Ackerveken G, Bonas U (2002) The xanthomonas type III effector protein AvrBs3 modulates plant gene expression and induces cell hypertrophy in the susceptible host. MPMI 15:637-646

Meldau S, Kastner J, von Knorre D, Baldwin IT (2014) Salicylic aciddependent gene expression is activated by locomotion mucus of different molluscan herbivores. Commun Integr Biol 7:e28728

Melotto M, Underwood W, Koczan J, Nomura K, He SY (2006) Plant stomata function in innate immunity against bacterial invasion. Cell 126:969-980

Melotto M, Mecey C, Niu Y, Chung HS, Katsir L, Yao J, Zeng W, Thines B, Staswick P, Browse J, Howe GA, He SY (2008) A critical role of two positively charged amino acids in the Jas motif of Arabidopsis JAZ proteins in mediating coronatine- and jasmonoyl isoleucine-dependent interactions with the COI1 F-box protein. Plant J 55:979-988

Minato N, Himeno M, Hoshi A, Maejima K, Komatsu K, Takebayashi Y, Kasahara H, Yusa A, Yamaji Y, Oshima K, Kamiya Y, Namba S (2014) The phytoplasmal virulence factor TENGU causes plant sterility by downregulating of the jasmonic acid and auxin pathways. Sci Rep 4:1399

Misas-Villamil JC, Kolodziejek I, Crabill E, Kaschani F, Niessen S, Shindo T, Kaiser M, Alfano JR, van der Hoorn RA (2013) Pseudomonas syringae pv. syringae uses proteasome inhibitor syringolin A to colonize from wound infection sites. PLoS Pathog 9:e1003281

Mitchum MG, Hussey RS, Baum TJ, Wang X, Elling AA, Wubben M, Davis EL (2013) Nematode effector proteins: an emerging paradigm of parasitism. New Phytol 199:879-894

Mou Z, Fan W, Dong X (2003) Inducers of plant systemic acquired resistance regulate NPR1 function through redox changes. Cell 113:935-944

Mutka AM, Fawley S, Tsao T, Kunkel BN (2013) Auxin promotes susceptibility to Pseudomonas syringae via a mechanism independent of suppression of salicylic acid-mediated defenses. Plant J 74:746-754
Nahar K, Kyndt T, Hause B, Hofte M, Gheysen G (2013) Brassinosteroids suppress rice defense against root-knot nematodes through antagonism with the jasmonate pathway. MPMI 26:106-115

Nam KH, Li JM (2002) BRI1/BAK1, a receptor kinase pair mediating brassinosteroid signaling. Cell 110:203-212

Naseem M, Kaltdorf M, Dandekar T (2015) The nexus between growth and defence signalling: auxin and cytokinin modulate plant immune response pathways. J Exp Bot 66:4885-4896

Navarro L, Dunoyer P, Jay F, Arnold B, Dharmasiri N, Estelle M, Voinnet O, Jones JD (2006) A plant miRNA contributes to antibacterial resistance by repressing auxin signaling. Science 312:436-439

Navarro L, Jay F, Nomura K, He SY, Voinnet O (2008) Suppression of the microRNA pathway by bacterial effector proteins. Science 321:964-967

Nomura K, Debroy S, Lee YH, Pumplin N, Jones J, He SY (2006) A bacterial virulence protein suppresses host innate immunity to cause plant disease. Science 313:220-223

Novakova M, Sasek V, Dobrev PI, Valentova O, Burketova L (2014) Plant hormones in defense response of brassica napus to sclerotinia sclerotiorum-reassessing the role of salicylic acid in the interaction with a necrotroph. Plant Physiol Biochem 80:308-317

Nurmberg PL, Knox KA, Yun BW, Morris PC, Shafiei R, Hudson A, Loake GJ (2007) The developmental selector AS1 is an evolutionarily conserved regulator of the plant immune response. Proc Natl Acad Sci USA 104:18795-18800

Padmanabhan MS, Goregaoker SP, Golem S, Shiferaw H, Culver JN (2005) Interaction of the tobacco mosaic virus replicase protein with the Aux/IAA protein PAP1/IAA26 is associated with disease development. J Virol 79:2549-2558

Padmanabhan MS, Shiferaw H, Culver JN (2006) The Tobacco mosaic virus replicase protein disrupts the localization and function of interacting Aux/IAA proteins. MPMI 19: 864-873

Padmanabhan MS, Kramer SR, Wang X, Culver JN (2008) Tobacco mosaic virus replicase-auxin/indole acetic acid protein interactions: reprogramming the auxin response pathway to enhance virus infection. J Virol 82:2477-2485

Pauwels L, Barbero GF, Geerinck J, Tilleman S, Grunewald W, Perez AC, Chico JM, Bossche RV, Sewell J, Gil E, Garcia-Casado G, Witters E, Inze D, Long JA, De Jaeger G, Solano R, Goossens A (2010) NINJA connects the co-repressor TOPLESS to jasmonate signalling. Nature 464:788-791

Pereira ALA, Carazzolle MF, Abe VY, de Oliveira MLP, Domingues MN, Silva JC, Cernadas RA, Benedetti CE (2014) Identification of putative TAL effector targets of the citrus canker pathogens shows functional convergence underlying disease development and defense response. BMC Genom 15:157

Pertry I, Vaclavikova K, Depuydt S, Galuszka P, Spichal L, Temmerman W, Stes E, Schmulling T, Kakimoto T, Van Montagu MCE, Strnad M, Holsters M, Tarkowski P, Vereecke D (2009) Identification of Rhodococcus fascians cytokinins and their modus operandi to reshape the plant. Proc Natl Acad Sci USA 106:929-934

Pertry I, Vaclavikova K, Gemrotova M, Spichal L, Galuszka P, Depuydt S, Temmerman W, Stes E, De Keyser A, Riefler M, Biondi S, Novak O, Schmulling T, Strnad M, Tarkowski P, Holsters M, Vereecke D (2010) Rhodococcus fascians impacts plant development through the dynamic fas-mediated production of a cytokinin mix. MPMI 23:1164-1174

Pieterse CM, Van der Does D, Zamioudis C, Leon-Reyes A, Van Wees SC (2012) Hormonal modulation of plant immunity. Annu Rev Cell Dev Biol 28:489-521 
Plett JM, Daguerre Y, Wittulsky S, Vayssieres A, Deveau A, Melton SJ, Kohler A, Morrell-Falvey JL, Brun A, Veneault-Fourrey C, Martin F (2014) Effector MiSSP7 of the mutualistic fungus Laccaria bicolor stabilizes the populus JAZ6 protein and represses jasmonic acid (JA) responsive genes. Proc Natl Acad Sci USA 111:8299-8304

Qiao Y, Liu L, Xiong Q, Flores C, Wong J, Shi J, Wang X, Liu X, Xiang Q, Jiang S, Zhang F, Wang Y, Judelson HS, Chen X, Ma W (2013) Oomycete pathogens encode RNA silencing suppressors. Nat Genet 45:330-333

Qiao Y, Shi J, Zhai Y, Hou Y, Ma W (2015) Phytophthora effector targets a novel component of small RNA pathway in plants to promote infection. Proc Natl Acad Sci USA 112:5850-5855

Radhika V, Ueda N, Tsuboi Y, Kojima M, Kikuchi J, Kudo T, Sakakibara H (2015) Methylated cytokinins from the phytopathogen Rhodococcus fascians mimic plant hormone activity. Plant Physiol 169:1118-1126

Reeves PH, Ellis CM, Ploense SE, Wu MF, Yadav V, Tholl D, Chetelat A, Haupt I, Kennerley BJ, Hodgens C, Farmer EE, Nagpal P, Reed JW (2012) A regulatory network for coordinated flower maturation. PLoS Genet 8:e1002506

Robert-Seilaniantz A, Navarro L, Bari R, Jones JD (2007) Pathological hormone imbalances. Curr Opin Plant Biol 10:372-379

Robert-Seilaniantz A, MacLean D, Jikumaru Y, Hill L, Yamaguchi S, Kamiya Y, Jones JD (2011) The microRNA miR393 re-directs secondary metabolite biosynthesis away from camalexin and towards glucosinolates. Plant J 67:218-231

Salehin M, Bagchi R, Estelle M (2015) SCFTIR1/AFB-based auxin perception: mechanism and role in plant growth and development. Plant Cell 27:9-19

Schaller GE, Bishopp A, Kieber JJ (2015) The yin-yang of hormones: cytokinin and auxin interactions in plant development. Plant Cell 27:44-63

Schellenberg B, Ramel C, Dudler R (2010) Pseudomonas syringae virulence factor syringolin A counteracts stomatal immunity by proteasome inhibition. MPMI 23:1287-1293

Schommer C, Palatnik JF, Aggarwal P, Chetelat A, Cubas P, Farmer EE, Nath U, Weigel D (2008) Control of jasmonate biosynthesis and senescence by miR319 targets. PLoS Biol 6:e230

Schroder G, Waffenschmidt S, Weiler EW, Schroder J (1984) The $\mathrm{T}$-region of $\mathrm{Ti}$ plasmids codes for an enzyme synthesizing indole-3-acetic acid. Eur J Biochem 138:387-391

Schulze B, Mentzel T, Jehle AK, Mueller K, Beeler S, Boller T, Felix G, Chinchilla D (2010) Rapid heteromerization and phosphorylation of ligand-activated plant transmembrane receptors and their associated kinase BAK1. J Biol Chem 285:9444-9451

Shan L, He P, Li J, Heese A, Peck SC, Nurnberger T, Martin GB, Sheen J (2008) Bacterial effectors target the common signaling partner BAK1 to disrupt multiple MAMP receptor-signaling complexes and impede plant immunity. Cell Host Microbe 4:17-27

Sheard LB, Tan X, Mao H, Withers J, Ben-Nissan G, Hinds TR, Kobayashi Y, Hsu F-F, Sharon M, Browse J, He SY, Rizo J, Howe GA, Zheng N (2010) Jasmonate perception by inositolphosphate-potentiated COI1-JAZ co-receptor. Nature 468: 400-405

Shyu C, Figueroa P, Depew CL, Cooke TF, Sheard LB, Moreno JE, Katsir L, Zheng N, Browse J, Howe GA (2012) JAZ8 lacks a canonical degron and has an EAR motif that mediates transcriptional repression of jasmonate responses in Arabidopsis. Plant Cell 24:536-550

Spoel SH, Dong X (2008) Making sense of hormone crosstalk during plant immune responses. Cell Host Microbe 3:348-351

Spoel SH, Dong X (2012) How do plants achieve immunity? Defence without specialized immune cells. Nat Rev Immunol 12:89-100
Spoel SH, Mou Z, Tada Y, Spivey NW, Genschik P, Dong X (2009) Proteasome-mediated turnover of the transcription coactivator NPR1 plays dual roles in regulating plant immunity. Cell 137:860-872

Staswick PE (2008) JAZing up jasmonate signaling. Trends Plant Sci 13:66-71

Staswick PE, Tiryaki I (2004) The oxylipin signal jasmonic acid is activated by an enzyme that conjugates it to isoleucine in Arabidopsis. Plant Cell 16:2117-2127

Sugio A, Kingdom HN, MacLean AM, Grieve VM, Hogenhout SA (2011) Phytoplasma protein effector SAP11 enhances insect vector reproduction by manipulating plant development and defense hormone biosynthesis. Proc Natl Acad Sci USA 108:E1254-E1263

Sun YD, Li L, Macho AP, Han ZF, Hu ZH, Zipfel C, Zhou JM, Chai JJ (2013) Structural basis for flg22-induced activation of the Arabidopsis FLS2-BAK1 immune complex. Science 342:624-628

Swarup K, Benkova E, Swarup R, Casimiro I, Peret B, Yang Y, Parry G, Nielsen E, De Smet I, Vanneste S, Levesque MP, Carrier D, James N, Calvo V, Ljung K, Kramer E, Roberts R, Graham N, Marillonnet S, Patel K, Jones JDG, Taylor CG, Schachtman DP, May S, Sandberg G, Benfey P, Friml J, Kerr I, Beeckman T, Laplaze L, Bennett MJ (2008) The auxin influx carrier LAX3 promotes lateral root emergence. Nat Cell Biol 10:946-954

Sweat TA, Wolpert TJ (2007) Thioredoxin h5 is required for victorin sensitivity mediated by a CC-NBS-LRR gene in Arabidopsis. Plant Cell 19:673-687

Tada Y, Spoel SH, Pajerowska-Mukhtar K, Mou Z, Song J, Wang C, Zuo J, Dong X (2008) Plant immunity requires conformational changes of NPR1 via S-nitrosylation and thioredoxins. Science 321:952-956

Takahashi S, Sato R, Takahashi M, Hashiba N, Ogawa A, Toyofuku K, Sawata T, Ohsawa Y, Ueda K, Wabiko H (2013) Ectopic localization of auxin and cytokinin in tobacco seedlings by the plant-oncogenic AK-6b gene of Agrobacterium tumefaciens AKE10. Planta 238:753-770

Tanaka H, Kitakura S, Rakusova H, Uemura T, Feraru MI, De Rycke R, Robert S, Kakimoto T, Friml J (2013) Cell polarity and patterning by PIN trafficking through early endosomal compartments in Arabidopsis thaliana. PLoS Genet 9:e1003540

Thines B, Katsir L, Melotto M, Niu Y, Mandaokar A, Liu G, Nomura K, He SY, Howe GA, Browse J (2007) JAZ repressor proteins are targets of the SCFCOI1 complex during jasmonate signalling. Nature 448:661-665

Thomashow MF, Hugly S, Buchholz WG, Thomashow LS (1986) Molecular basis for the auxin-independent phenotype of crown gall tumor tissues. Science 231:616-618

Thomma BP, Eggermont K, Tierens KF, Broekaert WF (1999) Requirement of functional ethylene-insensitive 2 gene for efficient resistance of Arabidopsis to infection by Botrytis cinerea. Plant Physiol 121:1093-1102

Torto-Alalibo T, Collmer CW, Lindeberg M, Bird D, Collmer A, Tyler BM (2009) Common and contrasting themes in host celltargeted effectors from bacterial, fungal, oomycete and nematode plant symbionts described using the Gene Ontology. BMC Microbiol 9:S3

Tsuda K, Sato M, Stoddard T, Glazebrook J, Katagiri F (2009) Network properties of robust immunity in plants. PLoS Genet 5:e1000772

Ustun S, Bornke F (2015) The Xanthomonas campestris type III effector XopJ proteolytically degrades proteasome subunit RPT6. Plant Physiol 168:107-119

Üstün S, Bartetzko V, Börnke F (2013) The Xanthomonas campestris type III effector XopJ targets the host cell proteasome to suppress salicylic-acid mediated plant defence. PLoS Pathog 9:e1003427 
Valls M, Genin S, Boucher C (2006) Integrated regulation of the type III secretion system and other virulence determinants in Ralstonia solanacearum. PLoS Pathog 2:e82

Van der Does D, Leon-Reyes A, Koornneef A, Van Verk MC, Rodenburg N, Pauwels L, Goossens A, Korbes AP, Memelink J, Ritsema T, Van Wees SCM, Pieterse CMJ (2013) Salicylic acid suppresses jasmonic acid signaling downstream of SCFCOI1JAZ by targeting GCC promoter motifs via transcription factor ORA59. Plant Cell 25:744-761

VanDoorn A, de Vries M, Kant MR, Schuurink RC (2015) Whiteflies glycosylate salicylic acid and secrete the conjugate via their honeydew. J Chem Ecol 41:52-58

Vanstraelen M, Benkova E (2012) Hormonal interactions in the regulation of plant development. Annu Rev Cell Dev Biol 28:463-487

Volksch B, Weingart H (1998) Toxin production by pathovars of Pseudomonas syringae and their antagonistic activities against epiphytic microorganisms. J Basic Microbiol 38:135-145

Walters DR, McRoberts N (2006) Plants and biotrophs: a pivotal role for cytokinins? Trends Plant Sci 11:581-586

Walters DR, McRoberts N, Fitt BDL (2008) Are green islands red herrings? Significance of green islands in plant interactions with pathogens and pests. Biol Rev 83:79-102

Wawra S, Belmonte R, Lobach L, Saraiva M, Willems A, van West P (2012) Secretion, delivery and function of oomycete effector proteins. Curr Opin Microbiol 15:685-691

Weingart H, Volksch B (1997) Ethylene production by Pseudomonas syringae pathovars in vitro and in planta. Appl Environ Microbiol 63:156-161

Weingart H, Ullrich H, Geider K, Volksch B (2001) The role of ethylene production in virulence of Pseudomonas syringae pvs. glycinea and phaseolicola. Phytopathology 91:511-518

White RF (1979) Acetylsalicylic acid (aspirin) induces resistance to tobacco mosaic virus in tobacco. Virology 99:410-412

Wildermuth MC, Dewdney J, Wu G, Ausubel FM (2001) Isochorismate synthase is required to synthesize salicylic acid for plant defence. Nature 414:562-565

Wong J, Gao L, Yang Y, Zhai J, Arikit S, Yu Y, Duan S, Chan V, Xiong Q, Yan J, Li S, Liu R, Wang Y, Tang G, Meyers BC, Chen X, Ma W (2014) Roles of small RNAs in soybean defense against Phytophthora sojae infection. Plant J 79:928-940

Wright CA, Beattie GA (2004) Pseudomonas syringae pv. tomato cells encounter inhibitory levels of water stress during the hypersensitive response of Arabidopsis thaliana. Proc Natl Acad Sci USA 101:3269-3274

Xiang T, Zong N, Zou Y, Wu Y, Zhang J, Xing W, Li Y, Tang X, Zhu L, Chai J, Zhou JM (2008) Pseudomonas syringae effector AvrPto blocks innate immunity by targeting receptor kinases. Curr Biol 18:74-80

Xu J, Audenaert K, Hofte M, De Vleesschauwer D (2013) Abscisic acid promotes susceptibility to the rice leaf blight pathogen Xanthomonas oryzae pv oryzae by suppressing salicylic acidmediated defenses. PLoS One 8:e67413

Yamaguchi K, Nakamura Y, Ishikawa K, Yoshimura Y, Tsuge S, Kawasaki T (2013) Suppression of rice immunity by Xanthomonas oryzae type III effector Xoo2875. Biosci Biotechnol Biochem 77:796-801

Yang JY, Iwasaki M, Machida C, Machida Y, Zhou X, Chua NH (2008) betaC1, the pathogenicity factor of TYLCCNV, interacts with AS1 to alter leaf development and suppress selective jasmonic acid responses. Genes Dev 22:2564-2577

Zarate SI, Kempema LA, Walling LL (2007) Silverleaf whitefly induces salicylic acid defenses and suppresses effectual jasmonic acid defenses. Plant Physiol 143:866-875

Zhang T, Luan JB, Qi JF, Huang CJ, Li M, Zhou XP, Liu SS (2012) Begomovirus-whitefly mutualism is achieved through repression of plant defences by a virus pathogenicity factor. Mol Ecol 21:1294-1304

Zheng X-Y, Spivey Natalie W, Zeng W, Liu P-P, Fu Zheng Q, Klessig Daniel F, He Sheng Y, Dong X (2012) Coronatine promotes Pseudomonas syringae virulence in plants by activating a signaling cascade that inhibits salicylic acid accumulation. Cell Host Microbe 11:587-596

Zhou J, Wu S, Chen X, Liu C, Sheen J, Shan L, He P (2014) The Pseudomonas syringae effector HopF2 suppresses Arabidopsis immunity by targeting BAK1. Plant J 77:235-245

Zhou Z, Wu Y, Yang Y, Du M, Zhang X, Guo Y, Li C, Zhou JM (2015) An Arabidopsis plasma membrane proton ATPase modulates JA signaling and is exploited by the Pseudomonas syringae effector protein AvrB for stomatal invasion. Plant Cell 27:2032-2041

Zhu JY, Sae-Seaw J, Wang ZY (2013) Brassinosteroid signalling. Development 140:1615-1620

Zipfel C (2014) Plant pattern-recognition receptors. Trends Immunol $35: 345-351$ 